\title{
A Non-Destructive Prediction Method for Wood Density Variations of Silver Birch Trees Growing in the Middle Volga Region, Russia
}

\author{
Vladimir llyich Fedyukov ${ }^{1 *}$, Musikhina Lydmila Anatolyevna ${ }^{1}$, Maria Sergeyevna Chernova ${ }^{1}$, \\ Olga Viktorovna Tsoy ${ }^{1}$, Nikita Andreyevich Magalyas ${ }^{1}$
}

(1) Volga State University of Technology, Department of Standardization, Certification and Merchandizing, Lenin Sq., 3, RU-424 000 Yoshkar-Ola, Russia

* Correspondence: e-mail: fiv48@mail.ru

\begin{abstract}
Citation: Fedyukov $\mathrm{VI}$, Anatolyevna ML, Chernova MS, Tsoy OV, Magalyas NA, 2020. A Non-Destructive Prediction Method for the Wood Density Variations of Silver Birch Trees Growing in the Middle Volga Region, Russia. South-east Eur for 11(1): 85-90. https://doi.org/10.15177/seefor.20-09.

Received: 22 Jan 2020; Revised: $20 \mathrm{Apr}$ 2020; Accepted: 7 May 2020; Published online: 24 Jun 2020
\end{abstract}

\begin{abstract}
The density of wood inside the stick varies greatly according to the diameter and height of the tree. The development of a non-destructive method of predicting an average density of wood in all specific breed stem-base density in parts of the tree is of great practical importance. For this purpose, the research was conducted to identify the patterns of wood density dynamics against the height and the diameter of birch trees growing in the conditions of the Middle Volga Region in Russia. Fourteen model birch trees (Betula pendula) were selected as research material on two plots in the plantations of the Scientific-Experimental Forest District of the Volga State University of Technology (VSUT) in the Republic of Mari El of Russia. From each felled model tree $50.0 \mathrm{~mm}$ cross-section discs were carved at a distance of $1.3 \mathrm{~m}$ from the root collar and at relative heights of $0.25 \mathrm{H}, 0.5 \mathrm{H}$, and $0.75 \mathrm{H}$. Prototypes in the form of $20 \times 20 \times 30 \mathrm{~mm}$ rectangular prisms (long side along the wood grain) were made from their north and south sides at a distance of $0.25 R, 0.5 R$ and $0.75 R$ from the stem core along the NS diagonal. Density studies were conducted by measuring the density of the wood sample immersed in liquid against the buoyant force. It has been revealed that there are both differences and patterns of change in density in the longitudinal and cross-section directions of the trunk of a birch tree growing in the conditions of the Middle Volga Region in Russia. Based on the results obtained, a mathematical model of these laws has been formulated. Close relationship between the average density of the stick and its diameter at breast height (DBH) cross-section average density, i.e. $\rho_{\text {tree }}=178.52+0.641 \rho_{\mathrm{dbh}}(r=0.922)$ has been revealed. By applying a well-known method of determining the density of crosssection radial core extracted from the wood by an age borer at this height, wood density of the birch trees growing in the Middle Volga Region can be calculated according to this equation.
\end{abstract}

Keywords: birch wood; tree slenderness coefficient method; height density of a tree; stick diameter density; nondestructive diagnosis of wood medium density.

\section{INTRODUCTION}

Scientists and experts from many countries across the world are engaged in the research of wood density of different species of growing trees and timber (Heräjärvi 2004, Repola 2006, Missanjo and Matsumura 2016, Beets et al. 2018, Lachowicz et al. 2019, Farias et al. 2020). Recently, this indicator has particularly gained fundamental importance in tackling global environmental problems, namely, in biomass inventory and carbon balance monitoring in various terrestrial ecosystems (Beets et al. 2018, Farias et al. 2020).

Up to the 1970s in Russia, no particular importance has been given to the research of the technical properties of wood, when wood raw material was in excess, and its cost was negligible. Industry needs regarding high-quality 
raw material were met mainly at the expense of pioneer development of new plantations. In subsequent years, the situation changed dramatically, as an acute shortage of highquality wood raw material was felt in the European part of the country. This initiated the execution of research work (Poluboyarinov 1976, Denisov 1999, Golyakov 2003, Kozlov et al. 2009, Danilov 2016, Platonov et al. 2018).

One of the priority studies of wood density variability inside the trunk of a tree was the fundamental work of Poluboyarinov (1976). Although the results were obtained in the plantations of the North-Western part of Russia, they have been of great scientific and practical interest for other regions.

In the forests of Russia birch is mostly widespread among the hardwood species. Two species, silver birch (Betula pendula Roth) and white birch (Betula pubescens Ehrh), predominate in growth area size and stock of standing wood among 70 species growing in these forests. Birch wood, especially of these species, has good physical and mechanical properties and is of great industrial importance. It is widely used for the production of sliced veneer and plywood, parquet, chipboard and fiberboard, pellets, as well as for manufacturing rifle stocks, skis, and construction elements. Birch is a valuable raw material for wood chemical and papermaking industries in obtaining charcoal, methyl alcohol, acetone, furfural, cellulose and many other products.

In this regard, wood density is extremely important for its industrial use. This is related to its impact on both the technology of wood raw material processing and the quality of the final product. For example, in terms of the problems of wood cutting, density significantly affects lumber manufacturing technology, as well as wear and tear of saws and other cutting tools (Pesotsky 1970, Chernov et al. 2019).

Nowadays, laminated structures made of wood are widespread, where the density also largely determines their characteristics. For example, a $60 \%$ increase in strength and a $45 \%$ increase in stiffness of the finished laminated product can be achieved only by the rational arrangement of bonded parts in beams taking into account wood density (Poluboyarinov 1976).

Many physical and mechanical operational characteristics of wood correlate with density: compressive and flexural strength, hardness, rigidity, durability, ability to hold metal fasteners, etc. (Volynsky 1991). In Russian (Interstate) standards the density of birch wood is normalized for lumber and aircraft work pieces according to GOST 968-68 (1968) and GOST 2996-79 (1979), as well as for blanks for sporting and hunting shooting gun stocks according to GOST 16424-83 (1983). In the pulp-and-paper and wood chemical industries the density is the main indicator of the quality of wood raw material, since it determines the relative yield per the unit of its volume.

The maximum density of raw material is of great practical importance for the production of all of the above-mentioned and many other products. It is the density that determines many physical and mechanical properties and specific yield of products from a unit of its volume. One promising way to achieve this goal is the implementation of a non-destructive diagnosis method of standing wood quality and the selection of the most promising trees with maximum density for further cultivation.

The situation is aggravated by the fact that even within the same species of wood density inside the stick along its height and diameter varies depending on the direct or indirect effect of the complex of factors - genetics, soil and climatic conditions of the habitat, forest indices of the stands themselves and, most importantly, geographic region of growth of the specific stands (Poluboyarinov 1976, Lachowicz et al. 2019).

Despite the significant prevalence of birch stands in the forests of Middle Volga Region (occupying about 32\% of the forested area), the studies of wood density have been rare hitherto (Denisov 1999) and there are no works directed at identifying the patterns of its variability (densitograms) inside the growing trees. Meanwhile, in recent years there has been an intensive use of birch stands as a source of raw material for wood processing enterprises in this region of Russia, denser wood with high technical characteristics being in special demand.

The purpose of the present work was to develop a nondestructive method for predicting standing wood density for rational use of available inventory of birch stands and, most importantly, their cultivation with specific intended purpose in the conditions of the Middle Volga Region in Russia.

\section{MATERIALS AND METHODS}

Birch stands of natural (seed) origin served as the object of the research on the territory of the Scientific-Experimental Forest District of the Volga State University of Technology (VSUT). Experimental plots are presented by birch and lime stands of 11 capacity classes characteristic for the Middle Volga Region. The type of site conditions is $\mathrm{C}_{2}$; the soil is sodcryptopodzolic, loamy, and fresh. Silver birch (Betula pendula Roth) dominates in the stand composition, while European aspen (Populus tremula Link) and Norway spruce (Picea excels Link) are sporadically found as well. The average age of birch trees is 70 years; their diameter at breast height (DBH) is approximately $30 \mathrm{~cm}$ and the height is $28.5 \mathrm{~m}$.

Two test areas were established in these stands according to GOST 16483.0-80. Seven sample trees based on the 'average model' were selected on each plot for characterizing the plot trees according to the main valuation factors, such as average diameter, height, crown shape, etc.

Before felling each model tree DBH was measured in two mutually perpendicular directions within the accuracy of 0.5 $\mathrm{cm}$, and blazing was made on the north side. The total length, the distance from the butt end to the first open dead branch to the live crown, as well as the stick diameter at relative heights of $0.25 \mathrm{H}, 0.5 \mathrm{H}$ and $0.75 \mathrm{H}$ were measured for each felled model tree. At each of these heights and at a height of $1.3 \mathrm{~m}$ a disc of about $50 \mathrm{~mm}$ was cut out from the stick (Figure 1).

The relative height sampling method has several advantages over the method of fixed height sampling typically used in taxational studies when wood samples are taken in 1, 2 or $3 \mathrm{~m}$. This former method simplifies the data processing on a computer and, more importantly, it allows to directly compare the density of different trees irrespective of their actual height by applying appropriate indicators on the graphs in the form of a densitorgam (Poluboyarinov 1976).

The discs were divided into halves as 'north' and 'south' parts. From each of them test samples were made in the form of rectangular prisms $20 \times 20 \times 30 \mathrm{~mm}$ at a distance of $0.25 \mathrm{R}$, $0.5 \mathrm{R}$ and $0.75 \mathrm{R}$ from the pith (Figure 2 ). 


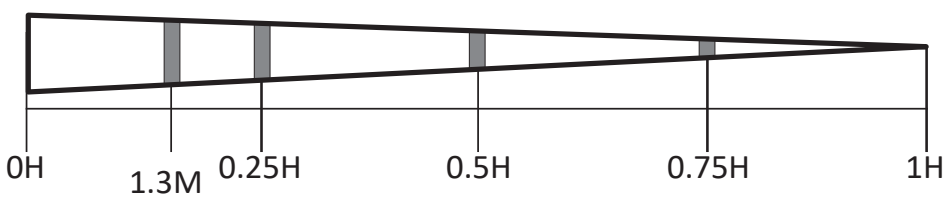

Figure 1. Cross-section severing of a model for taking test discs scheme.

In the study of physical properties of birch wood its density was determined by its basic density $\left(\rho_{\text {bas }}, \mathrm{kg} \cdot \mathrm{m}^{-3}\right)$ which is expressed by the ratio of the weight of an oven-dry sample $\left(\mathrm{m}_{0}\right)$ to its maximum volume $\left(\mathrm{V}_{\max }\right)$ at humidity equal to or above the saturation limit of the cell walls:

$$
\mathrm{P}_{\text {bas }}=\mathrm{m}_{0} / \mathrm{V}_{\max }
$$

The physical meaning of the basic density of wood is in the fact that it shows the amount of absolutely dry wood substance contained in a unit of its wet volume; this rate is independent of the humidity of the sample, which simplifies the process of laboratory determination compared with the conventional density $\rho_{w}$.

There are several ways of determining basic density, but the method in which the volume is calculated by measuring the buoyancy force of the samples immersed in liquid is the most convenient (a sample can have different geometrical shape) (Poluboyarinov 1976). A detailed description of this method is presented in our previously published work (Fedyukov et al. 2019).

The average density of the cross-section of a stick $\left(\rho_{c s}\right)$ was determined by the method of Poluboyarinov (1976) as a weighted average of densities $\rho_{0.25 R^{\prime}} \rho_{0.5 R^{\prime}} \rho_{0.75 R^{\prime}}$. If we take

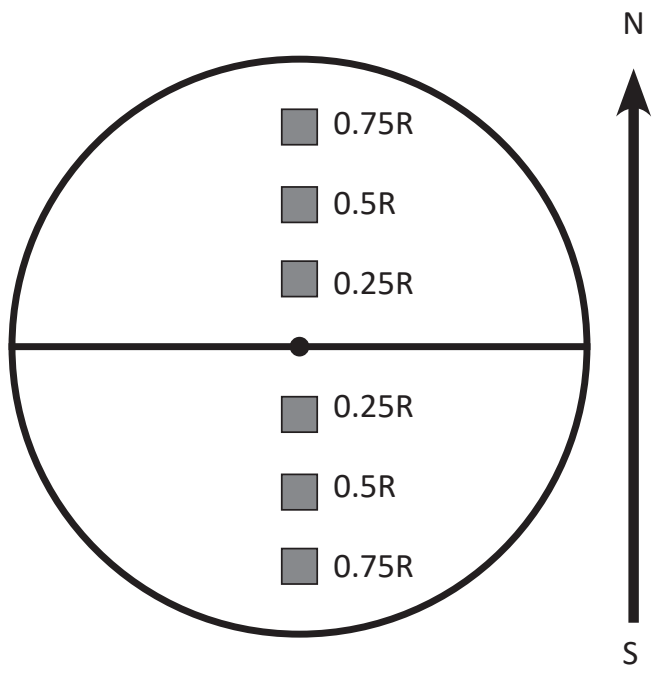

Figure 2. Making of test samples from the discs. the cross-sectional area of the stick as $100 \%$, the average density of the cross-section will equal to:

$$
\mathrm{P}_{\mathrm{cs}}=\frac{\rho_{0.25 \mathrm{R}} * 7+\rho_{0.5 \mathrm{R}} * 29+\rho_{0.75 \mathrm{R}} * 64}{100}
$$

where $\rho_{1.3 m}, \rho_{0.25 R}, \rho_{0.5 R}, \rho_{0.75 R}$ are wood densities at distances of $0.25 R, 0.5 R$ and $0.75 R$ from the pith; $V_{1.3 \mathrm{~m}^{\prime}}, V_{0.25 \mathrm{H}^{\prime}}$ $\mathrm{V}_{0.5 \mathrm{H}^{\prime}}, \mathrm{V}_{0.75 \mathrm{H}}$ are the areas (in per cent) occupied by wood ring area.

The average basal stick density was determined as the weighted average of the densities of the individual parts (discs) along its height:

$P_{\text {tree }}=\frac{\rho_{1.3 \mathrm{~m}} * \mathrm{~V}_{1.3 \mathrm{~m}}+\rho_{0.25 \mathrm{H}} * \mathrm{~V}_{0.25 \mathrm{H}}+\rho_{0.5 \mathrm{H}} * \mathrm{~V}_{0.5 \mathrm{H}}+\rho_{0.75 \mathrm{H}} * \mathrm{~V}_{0.75 \mathrm{H}}}{\mathrm{V}_{1.3 \mathrm{~m}}+\mathrm{V}_{0.25 \mathrm{H}}+\mathrm{V}_{0.5 \mathrm{H}}+\mathrm{V}_{0.75 \mathrm{H}}}$

where $\rho_{1.3 \mathrm{~m}}, \rho_{0.25 \mathrm{H}}, \rho_{0.5 \mathrm{H}}, \rho_{0.75 \mathrm{H}}$ are stick cross-section (disc) density at $1.3 \mathrm{~m}, 0.25 \mathrm{H}, 0.5 \mathrm{H}$ and $0.75 \mathrm{H}$ height; $\mathrm{V}_{1.3 \mathrm{~m}^{\prime}}$ $\mathrm{V}_{0.25 \mathrm{H}}, \mathrm{V}_{0.5 \mathrm{H}}, \mathrm{V}_{0.75 \mathrm{H}}$ are the volumes of separate sections (discs) along the stick height.

To determine the basic density by Equation 1 the method based on measuring the buoyancy force of the samples immersed in liquid was used. A detailed description of this method is presented below (Figure 3).

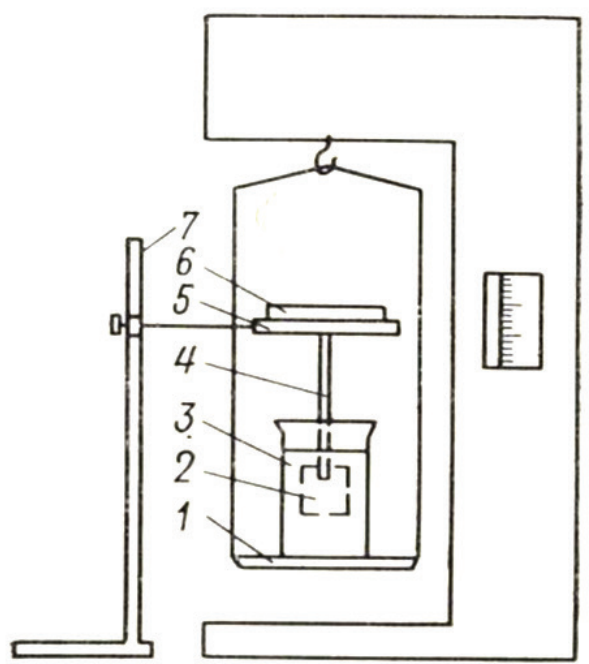

Figure 3. Diagram of the device for determining wood density by measuring the buoyancy: 1 - weighing pan; 2 - sample; 3 - a vessel with water; 4 - needle; 5 - ring; 6 - holder; 7 - tripod. 
A vessel with water (3) is placed on the weighing pan (1). The ring (5) fixed to the tripod (7) is placed above the vessel. The ring serves as a support for the holder (6) which has a needle (4) with its end doused into water. In this position, the vessel with water is weighed. After that, the holder is removed and the sample (2), previously held in water, is placed onto the needle to determine its volume. After immersing the sample, a second report is taken. An additional load on the weighing pan is created by overcoming the buoyant force acting on the sample (Archimedes' principle) and numerically equal (if we take the density of water equal to 1 ) to the sample volume. Consequently, the difference in readings on the scale gives the desired volume in cubic centimeters.

The sample mass in dry conditions will be determined by weighing on an electronic scale after drying at $103^{\circ} \mathrm{C}$ for about 10 hours.

\section{RESULTS AND DISCUSSION}

\section{Changing of Wood Density along the Trunk Radius}

According to Table 1, the general character of wood density distribution along the trunk diameter coincides approximately with the results of modern research in other countries (Repola 2006, Missanjo and Matsumura 2016). However, the densitogram received by Poluboyarinov (1976) for this species in the conditions of the North-West region of Russia (Leningrad and Novgorod regions) (Poluboyarinov 1976) is the closest to it.

Meanwhile, there are some differences in wood density variation in the transverse direction, which is observed in the apical part where density gradually increases from the center towards the periphery, while for the birch in the above-mentioned region this occurs only up to 0.4 part of the radius, and there is a further slight decline.

\section{Changing of Wood Density along the Trunk Height}

In absolute terms the average wood DBH is close to the results previously obtained in the region of research (Denisov 1999), i.e. about $500.0 \mathrm{~kg} \cdot \mathrm{m}^{-3}$ for silver birch, which is higher than that of white birch $\left(476.0 \mathrm{~kg} \cdot \mathrm{m}^{-3}\right)$. Table 2 shows that birch wood density decreases in a smooth manner along the trunk height.

This densitogram is consistent with the results obtained by other researchers in the past (Ugolev 2001, Danilov 2016) and nowadays (Heräjärvi 2004, Repola 2006, Kozlov et al. 2009, Platonov et al. 2018). For example, in Repola (2006) data are given on lower vertical dependence of birch density compared with spruce and pine. This is explained by the crown structure's specific nature and the way of natural pruning of the stick from the knots. The birch as a light-demanding species undergoes a relatively fast natural pruning of the stick from the knots, and, consequently, the stick with a high raised crown is formed. The annual layers formed at a considerable distance from the live crown have a high percentage of late wood and, accordingly, high density.

As for the wood decrease in density along the birch stick, it appears due to the increase of the vessel area and percentage of parenchyma when approaching the top of a tree (Platonov et al. 2018).

A more detailed analysis presented in Table 1 and Table 2 shows that the reduction in density from the peripheral zone to the core wood is approximately $9.5 \%$, and from the butt end to the top of the tree it is $5.9 \%$. From a technical point of view, e.g. when severing entire tree length into timber assortments, wood density changes along the tree height within $6 \%$ are not significant. Density dynamics in horizontal planes of a stick cross-section are of greater practical importance, because they determine the significant difference of specific yield of high-level assortments, as well as the dry matter of the core and peripheral areas of the stick.

Table 1. Changing of the birch wood basic density along the trunk radius.

\begin{tabular}{cccc}
\hline \multirow{2}{*}{$\begin{array}{c}\text { Cross-section height of stick } \\
\text { height fractions }\end{array}$} & \multicolumn{3}{c}{ Basic density of stick cross-section fractions $\left(\mathrm{kg} \cdot \mathrm{m}^{-3}\right)$} \\
\cline { 2 - 4 } & $\mathbf{0 . 2 5 R}$ & $\mathbf{0 . 5 R}$ & $\mathbf{0 . 7 5 R}$ \\
\hline $1.30 \mathrm{~m}$ & 483 & 509 & 543 \\
$0.25 \mathrm{H}$ & 479 & 502 & 521 \\
$0.50 \mathrm{H}$ & 474 & 508 & 517 \\
$0.75 \mathrm{H}$ & 461 & 484 & 507 \\
\hline
\end{tabular}

Note: the average density of the stick section is obtained as the arithmetic mean of the zone sections.

Table 2. Changing of the birch wood basic density along the trunk height.

\begin{tabular}{ccccccc}
\hline \multirow{2}{*}{$\begin{array}{c}\text { Cross-section height of stick } \\
\text { height fractions }\end{array}$} & $\begin{array}{c}\text { Arithmetical average } \\
\left(\mathrm{kg} \cdot \mathrm{m}^{-3}\right)\end{array}$ & $\begin{array}{c}\text { Standard deviation, } \\
\boldsymbol{\sigma} \pm\left(\mathrm{kg} \cdot \mathrm{m}^{-3}\right)\end{array}$ & $\begin{array}{c}\text { Coefficient of variation, } \\
\mathbf{V}(\%)\end{array}$ & $\begin{array}{c}\text { Error of mean, } \\
\mathbf{m} \pm\left(\mathrm{kg} \cdot \mathrm{m}^{-3}\right)\end{array}$ & $\begin{array}{c}\text { Accuracy factor, } \\
\mathbf{P}(\%)\end{array}$ \\
\cline { 2 - 7 } & 512.0 & 39.74 & 7.76 & 8.67 & 1.69 \\
$1.30 \mathrm{~m}$ & 501.0 & 32.23 & 6.44 & 7.03 & 1.4 \\
$0.25 \mathrm{H}$ & 495.0 & 28.15 & 5.69 & 6.63 & 1.34 \\
$0.50 \mathrm{H}$ & 482.0 & 28.11 & 5.83 & 6.45 & 1.34 \\
\hline $.75 \mathrm{H}$ & & &
\end{tabular}


Consequently, there are less sharp dynamics of decline in density along the height of the tree than the increase in density from the center to the peripheral area in the horizontal plane in all sections of the tree trunk.

The results obtained confirm that the general nature of the change (decrease) in wood density along the trunk height is also consistent with the densitogram of the birch growing in the North-Eastern part of Russia (Poluboyarinov 1976), as well as elsewhere in the world (Repola 2006, Lachowicz et al. 2019).

\section{Mathematical Models for Predicting Wood Density Inside the Tree Trunk}

Previous studies also found out that there is a close correlation between the average density of the whole stick and individual density of its levels. Thus, for ripe even-aged stand of wood sorrel spruce forest in Leningrad region the dependence is obtained (Poluboyarinov 1976):

$$
y=34.09+0.911 \cdot x
$$

where $\mathrm{y}$ is stick average density in $\mathrm{kg} \cdot \mathrm{m}^{-3}$; $\mathrm{x}$ is density at breast height in $\mathrm{kg} \cdot \mathrm{m}^{-3}$.

In birch and lime forest we also established a close relationship between wood density $\left(\rho_{\text {tree }}\right)$ and average density of a cross-section at a height of $1.3 \mathrm{~m}\left(\rho_{1.3}\right)$ :

$$
\rho_{\text {tree }}=178.52+0.641 \cdot \rho_{1.3} \quad r=0.922
$$

The average density of the stick was calculated by the above Equation (4); the average cross-sectional density was determined according to Equation (5). Differences in the cross-sectional density according to zones and the areas of these zones were taken into account.

For birch the relationship was established between the average density of the stick cross-section $\left(\rho_{c s}\right)$ and wood density in the peripheral zone $\left(\rho_{0.75 R}\right)$ of this cross-section:

$$
\rho_{c s}=67.3+0.853 \rho_{0.75 R} \quad r=0.982
$$

Based on the findings of the existence of a specific pattern of wood density change according to the zones, we obtained the relationship between tree density and wood density of the peripheral zone at a height of 1.3 meters:

$$
\rho_{\text {tree }}=223.3+0.542 \rho \begin{aligned}
& 1.3 \\
& 0.75 R \quad r=0.839
\end{aligned}
$$

It is important to note that in this case it is not required to take cores from the whole radius of a stick, which greatly simplifies the process and, more importantly, is less traumatic for the tree.

To study the pattern of wood density changing inside the stick let us consider basic density of the peripheral cross-section of the stick (0.75R) at the height of $1.3 \mathrm{~m}$ to be $100 \%\left(\rho_{\text {bas }}^{1.3}{ }_{075 R}\right)$. Let us determine the basic density for each stick zone under study $\left(\rho_{\text {basi }}\right)$ with coordinates $\left(\frac{h}{H} ; \frac{r}{R}\right)$ as a percentage with respect to $\rho_{\text {bas }}{ }_{075 R}^{1.3} \cdot \frac{h}{H}$ showed the following values: $0.06(1.3 \mathrm{~m}) ; 0.25 ; 0.5$ and $0.75 ; \frac{\mathrm{r}}{\mathrm{R}}$ ratio showed 0.25 ; 0.5 and 0.75 , respectively.

Then the definiendum of the experiment, i.e. the relative basic density of $\mathrm{i}^{\text {th }}$ zone of the stick, $\mathrm{y}$, is

$$
\mathrm{y}=\frac{\rho_{\text {bas }_{\mathrm{i}}}}{\rho_{\text {bas }_{0.75 \mathrm{R}}} 1.3} * 100
$$

The following regression equation is obtained with the aid of a computer:

$$
y=85.55-7.33 \frac{h}{H}+16.99 \frac{r}{R}
$$

After verifying the equation $\left(\mathrm{F}_{\text {calc }}=1.6<\mathrm{F}_{\text {tab }}=2.1\right.$ for $q=0.05$ ) and substituting $y$ by the value in Equation (8) we obtain:

$$
\rho_{\text {basi }}=\rho_{\text {bas }}{ }_{075 R}^{1.3} \cdot 10^{-2} \cdot\left(85.55-7.33 \frac{\mathrm{h}}{\mathrm{H}}+16.99 \frac{\mathrm{r}}{\mathrm{R}}\right)
$$

\section{CONCLUSIONS}

The average density of the stick wood can be determined non-destructively by taking a radial cross-section core with the diameter of about $4.0 \mathrm{~mm}$ from a growing tree using Bressler's increment borer. The procedure can be limited by the depth of drilling no more than $0.25 \mathrm{DBH}$. Once the basic density of the sample has been determined by buoyancy force method, the average density of the whole stick can be predicted on the basis of the laws governing the distribution of wood density within a particular wood species tree in respective stands.

This opens the practical possibility to predict wood quality of growing trees, which is the basis of cultivating the target forest with specified technical properties (density) of raw material for strictly special purposes.

\section{Author Contributions}

VIF, MLA conceived and designed the research and carried out the field measurements; MSCh, OVTs and NAM performed laboratory analysis; MLA, MSCh and OVT processed the data and performed the statistical analysis; VIF supervised the research and helped to draft the manuscript; VIF and MLA wrote the manuscript.

\section{Funding}

This research is an initiative author's project and it has no external funding.

\section{Acknowledgments}

This research was made possible thanks internal funding of the Department of Scientific and Innovative Activity a Volga State University of Technology and to the support its Dep. head prof. Andrianova Yu.S. personally.

\section{Conflicts of Interest}

The authors declare no conflict of interest. 


\section{REFERENCES}

Beets PN, Kimberley MO, Oliver GR, Pearce SH, 2018. Predicted wood density of growth increments of Douglas-fir stands in New Zealand. New Zeal J For Sci 48(1): 8. https://doi. org/10.1186/s40490-018-0112-z.

Chernov VY, Sharapov YeS, Toropov AS, 2019. Determination of wood density by measuring drilling resistance. Volga State University of Technology, Yoshkar-Ola, Russia, 200 p.

Danilov DA, 2016. Features of mixed stands formation, product structure and wood density of pine and spruce trees. Extended Abstract of Doc. Sc. Dissertation, St. Petersburg, Russia, 41 p.

Farias HLS, Silva WR, Perdiz RO, Citó AC, Carvalho LCS, Barbosa RI, 2020. Dataset on wood density of trees in ecotone forests in Northern Brazilian Amazonia. Data in Brief 30: 105378, 39 p. https://doi.org/10.1016/i.dib.2020.105378.

Fedyukov VI, Saldaeva EY, Chernova MS, Chernov VY, 2019. Research into dendro-acoustic properties of introduced clones' wood as material for manufacturing musical instruments. South-East Eur For 10(2): 173-179. https://doi. org/10.15177/seefor.19-18.

Golyakov AD, 2003. On Investigation of Pine Wood Density. Lesnoy zhurnal 1: 137- 138.

GOST 968-68, 1968. Sawn timber (bars and boards) for aircraft. Specifications, Moscow, Russia, 24 p. Available online: http:// docs.cntd.ru/document/1200016946 (2 June 2020).

GOST 2996-79, 1979. Blanks of foliage tree species for aviation. Specifications, Moscow, Russia, 22 p. Available online: https:// files.stroyinf.ru/Index2/1/4294825/4294825274.htm (2 June 2020).

GOST 16424-83, 1983. Blanks for sporting and hunting shooting gun stocks. Specifications, Moscow, Russia, 12 p. Available online: http://docs.cntd.ru/document/1200016974 (2 June 2020).
Heräjärvi H, 2004. Variation of basic density and Brinell hardness within mature Finnish Betula pendula and B. pubescens stems. Wood Fiber Sci 36(2): 216-227.

Kozlov VA, Kisternaya MV, Neronova JA, 2009. Influence of Forestry Measures on Density and Chemical Wood Composition of Scotch Pine. Lesnoy zhurnal 6: 7-13.

Lachowicz H, Bieniasz A, Wojtan R, 2019. Variability in the basic density of silver birch wood in Poland. Silva Fenn 53(1): 9968. https://doi.org/10.14214/sf.9968.

Missanjo E, Matsumura J, 2016. Wood Density and Mechanical Properties of Pinus kesiya Royle ex Gordon in Malawi. Forests 7(7): 135. https://doi.org/10.3390/f7070135.

Pesotsky AN, 1970. Sawing production. Forestry industry, Moscow, Russia, 438 p.

Platonov AD, Mikheyeva MA, Snegiryova SN, Kouryanova TK, Kiselyova AV, Topchev AN, 2018. The impact of vessels variability on the quality of birch and aspen in the tree stick. Lesnoy zhurnal 2: 212-221.

Poluboyarinov OI, 1976. Wood density. Forestry industry, Moscow, Russia, $159 \mathrm{p}$.

Repola J, 2006. Models for vertical wood density of Scots pine, Norway spruce and birch stems, and their application to determine average wood density. Silva Fenn 40(4): 673-685. https://doi.org/10.14214/sf.322.

Ugolev BN, 2001. Wood science with basic concepts of timber merchandizing. Moscow State Forestry, Russia University, Moscow, Russia, $340 \mathrm{p}$.

Volynsky VN, 1991. On the interconnection of wood strength with some of its parameters. Lesnoy zhurnal 4: 60- 64. 